\title{
Challenges and Prospects of Implementing Procurement Law in a Developing Economy: An X-ray of Oyo State Procurement Law
}

\author{
K. Shittu Adebisi
}

\begin{abstract}
Public procurement legislative reforms have proved to be a veritable economic development mechanism. This reform seeks to streamline, legalize and institutionalize public procurement practices in order to achieve the objectives of transparency, accountability, probity and anti-corruption. Using the Polytechnic Ibadan as a case-study, the paper X-ray some of the basic features and expectations of public procurement law regime. It observes that procurement law regime seeks to achieve the purpose of good governance through institutionalization of standard procurement practices. The data collection tool used was structured closed and open -ended questionnaires for the respondents who had been involved in the procurement process including survey of related literature on public procurement. In the course of testing the hypotheses, regression analysis was used to test the impact of public procurement in the execution of capital projects. The result of the findings reveals that Public Procurement Law had not made any significant impact on the execution of capital projects in the Polytechnic, Ibadan. The paper posits that if Nigeria nation must achieve the objectives of openness, transparency, probity, accountability and reduced corruption in line with global best governance institutional reform agenda, efforts should be intensified to deepen public procurement practices across all the government institutions
\end{abstract}

Index Terms-public procurement law, accountability, transparency, anti-corruption and economic development

\section{INTRODUCTION}

The need to fast-track development horizon in Africa and other underdeveloped countries of the world is never an easy task. It requires taking some hard choices, punching and jettisoning old methods of doing things that have contributed to underdevelopment and stagnations [1]. Faster growth and development requires critical public procurement reforms and some measures of openness, transparency and accountability as against the old opaque methods and secrecy in public transactions. Public procurement law is seen as the most essential aspects of development facilitation mechanisms geared towards the achievement of desired sustainable growth and development. In Africa and Nigeria in particular, public procurement reform is expected to introduce acceptable benchmarks for legitimacy in public affairs while promoting economic choices among people and institutions. Part of the major benefits of public procurement reform is that it helps entrench transparency, accountability, openness and appropriate value for money in all matters that concerns public procurements [2].

Apart from the fact that the old pre-public procurement reform era in Nigeria gives rooms for impurity, it was also extremely difficult to get best value for money in public procurement practices. There is absolute lack of strong regulatory framework. Government contracts and public procurements became easy avenues for rip offs by various shades of contractors with collaborative support of Nigerian public officials [3]. The public procurement law regime have proved to be a veritable tool for good governance and seeks to streamline, legalize and institutionalize public procurement practices in order to achieve the objectives of transparency, accountability, probity and anti-corruption.

While the Federal government of Nigeria has tried to adopt public procurement law regime to achieve the goal of good governance most of the 36 federating states seem not interested. Some federating states have out-rightly refused to adopt public procurement regime as a good governance mechanism. Others who tried to adopt the agenda did it halfheartedly by whittling down the force of the law. A key reason for this is that the status quo benefits the political class [4]. This situation has aggravated under development crisis, it has stunted growth and engender poverty in Nigeria.

The cardinal objective of Public Procurement Law 2007 is to pro-actively address past anomalies and defects in public procurement systems. This include absence of ombudsman regulatory institution, lack of procurement thresholds and the need to effectively drive public procurement process in order to achieve accountability, transparency, openness, value for money and zero-corruption [5[, [6]. The provisions of the Code of Conduct for Public Procurement in the Law are focused on anti-corruption, which is applicable to all public officers, suppliers, contractors and service providers. The Code of Conduct is applicable when making requisition for or planning of procurements, preparing solicitation documents, receiving offers in response to any form of solicitation etc. The Public Procurement Law also contains provisions for sanctions mechanism which seeks to make its implementation effective.

Public institutions have been bedeviled with the spate of corruption through the manipulation of the lacunas in the public procurement laws with the Nigerian higher educational institutions that supposed to be the custodian of the societal 
core value not left out of the cankerworm. The number of corrupt charges filed by the anti- graft agencies against the management of some higher institutions in Nigeria call for serious concern. Consequently, this research work endeavor to assess the extent of compliance to the public procurement law by the management of the Polytechnic Ibadan.

\section{STATEMENT OF PROBLEM}

Globally governments are increasingly under strain to provide host of essential services including health, education, defense, infrastructure, etc. To provide these essential services, governments purchase goods and services from the market place through public procurement broadly defined as the purchasing, hiring or obtaining by any other contractual means goods, construction works and services by the public sector. Reformed public procurement has important economic and political implications, ensuring that the process is economical and efficient. Abuse of office through corruption of public official, including providers of basic services, is widely recognized as endemic at all levels in Nigeria to the extent that graft has turned public services for many civil servants and their cohorts, into a kind of criminal enterprise. Manipulation, abuse, misappropriation, mismanagement and apparent diversion of public resources and assets for selfish ends is a common phenomenon among political actors and public officials who are collectively charged with responsibility of how such resources are allocated, managed and maximized to ensure value for money. This lack of accountability and transparency in the public governance call the attention of governments all over the world to the need to bring about radical attitudinal change over how government resources are accumulated and utilized toward the betterment of the citizens and to ensure good governance [7].

Despite the importance of the Public Procurement Law which is meant to curb corruption in the administration of public resources, few studies have specifically focused on the challenges and prospects in the implementation of the Public Procurement Law with specific reference to state tertiary institutions. Considering, the monumental infrastructural decay in our tertiary institutions, there is greater need to assess the implementation and compliance to Public Procurement Law with respect to capital projects. This study is out to bridge this gap by evaluating the challenges and prospects in the implementation to Public Procurement Law in the Polytechnic, Ibadan, Oyo State.,

\section{OBJECTIVES OF THE STUDY}

In line, with the statement of the problem above, the major objectives of this research are:

1) To determine the impacts of Public Procurement Law in the execution of projects in the Polytechnic, Ibadan, Oyo State.

2) To examine the understanding of public procurement law and its compliance in the Polytechnic's tendering process.

\section{RESEARCH HYPOTHESES}

The following research hypotheses have been formulated for testing in the course of this study:

H01: The Implementation of public procurement law has not made any significant impact on the execution of projects in the Polytechnic, Ibadan.

\section{LITERATURE REVIEW}

\section{A. General principles of public procurement}

[8] opine that effective and efficient procurement policies are important in assessing the performance of governments. However, [8] pointed out that there is no sufficient evidence by which successful procurement reforms can be measured due to lack of analysis and available information on return on investment on procurement reforms which has made the formulation of proposals difficult for new multilateral laws in procurement. There is therefore need for research to shed light on the success or otherwise of public procurement reforms in a range of developing countries and to provide case evidence and national experience that will inform reform strategies and international rule making. In the same vein, [9] added that much tends to be claimed for the benefits of the procurement reforms, but there is little analysis whether these benefits were actually realized after the reform initiatives occurred.

Procurement is the action or process of acquiring or obtaining material, property, or services at the operational level. The procurement process therefore involves planning, purchasing, contracting, and negotiating directly with the source of supply [10]. Some indeed view procurement as a fancy word for "purchasing and supply". Modern procurement practices however appear more extensive than the old concept of purchasing and supply. Usually, the procurement department within an organization manages all the major purchases with the exclusion of staff hiring [11]. Few Studies have been carried out on the Nigerian Public Procurement Reform. While [12] examined the Due Process Policy Model, [13] investigated the Due Process as a procurement method and its legal and institutional framework. [14] evaluated the levels of compliance with some of the provisions of the Budget Monitoring and Price Intelligence Unit. This study relates with aforementioned studies because the Due Process Policy and the Budget Monitoring and Price Intelligence Unit were the initial institutional arrangements of the Public Procurement Reform in Nigeria and were based on fundamental principles of the Public Procurement Act, 2007 and the Oyo State public procurement law 2010 even before their enactment. However, this study goes further as a pioneering study to evaluate actual impact of the Public Procurement Reform from the perspective of the polytechnic syste.

The set objectives of Nigerian Public Procurement Reform and its provisions/procedures are considered to be sound and capable of achieving the desired impact if well implemented [15[. The challenges of the Public Procurement in Nigeria have not been different from that of many other developing nations. Most of these difficulties relate to lack of fiscal transparency and public accountability, in addition to the inadequacy of resources for providing public infrastructures [16]. For example, in Nigeria, prior to the re-emergence of the democratic governance in 1999, Public Procurement delivery was subject to several irregularities which resulted in frequent failures. These included poor planning, insufficient budgeting plans, unnecessary project 
fragmentation, initial bids inflation and over invoicing, gross change orders during project execution, adoption of inappropriate procurement methods, contract allocation as opposed to competitive tendering, proliferation of incompetent contractors in the tendering process and deteriorating ethical standards of public Procurement practitioners. According to [13], these anomalies resulted in high project time and cost overruns, job abandonment, improper contract determination, conflicts and litigations, defective job performances and building collapses. [12] stated that contractor selection was not based on value and merits of bid but on tender price and initial lowest bid. The consequence was that Nigeria ranked highest worldwide in the cost of public projects execution [17]. This made the need for the procurement reform in Nigeria to become pertinent.

The persistent inadequacy of infrastructural facilities to meet the needs of the Nigerian economy coupled with the poor fiscal realities necessitated the dire need for optimal utilization of scarce resources appropriated for the public capital projects delivery. Furthermore, with globalization and advances in information technology, citizens began to demand for greater accountability and efficiency from government and the demands and expectations of the global economy on improving transparency and competition in government procurement added to the need to align and harmonize omission for International Trade Law (UNCITRAL) model and the World Bank guidelines. Thus, the Public Procurement Reform was introduced to improve service delivery generally in the public sector through focusing on principles and procedures in procurement that would place the country firmly on the path of economic growth. In the public sector, the reform is expected to promote a sustainable built environment through the application of competition in tendering, effective planning and budgeting for projects and the promotion of global best practices and ethical standards in order to achieve value for money on public building projects.

\section{B. X-Ray of Public Procurement Practices in Oyo State}

There is a close resemblance between experiences at the federal level of government in Nigeria and Oyo state in public procurement reform scheme. The public procurement mechanism in Oyo state passed through three unique stages. These are: Pre-Due Process Stage; Due Process mechanism stage and the stage of Oyo state Public Procurement Law 2010 regime. The Pre-Due Process stage was an era when there was no formalized, responsive public procurement system. The era pre date 1999 and it is not peculiar to Oyo state. It was a normal practice by all tiers of government at this stage to operate haphazard public procurement policies. There were no unified mechanisms. Government did not enjoy best value for money and there were no transparency. No standard operational framework for public procurement practices. The pre due-process stage was also characterized by various procurement abuses. They were over-invoicing, contract cost inflations, arbitrary pricing and poor tracking of performances. The stage also gave room for unethical and sharp practices. At its peak, Oyo state like other tiers of government (Federal, states and local) were grossly enmeshed in financial recklessness. Government contracts became easy avenues for rip-offs, corrupt practices and there were reckless contract infractions by various shades of contractors mostly with the support of public officials.

The Due-Process Mechanism stage in Oyo state was a spillover of initial reforms by the federal government of Nigeria. Consequent upon the setting up of Budget Monitoring and Price Intelligence Unit (BMPIU) by the federal government as a stop-gap due-process measure, other states keyed into the scheme with the aim of enhancing duediligence in public procurements practices and other contract related awards so as to achieve fair deal for government through price monitoring. Specifically, Oyo state government under Senator Rasheed Ladoja follow the footstep of federal government by instituting Budget Monitoring and Price Intelligence Unit (BMPIU) popularly called Due Process Unit under a Special Adviser. Alao Akala on assumption of office in 2007 followed suit by putting more relevance and effectiveness into the office of the Special Adviser on due process with responsibilities that include development of procurement core-parameters. The Unit established threshold of approvals, encourage evaluation of bids while it becomes resolute on right process, right winner and right price with focus on competitive lowest responsive evaluated bid. The Unit also embarks on issuance of certificate of award and other post-contract award monitoring activities.

There is no doubt that the due process mechanism was able to assist Oyo state in a number of ways. It helps to develop a unified procurement format for the state. It assists in getting best-value for money invested in procurements by the state to some extent. It also ensures that procurement proposals comply with checklist on competitiveness and transparency. Oyo state government was able to save money because due process mechanism gives room for post-award project monitoring. Nevertheless, there are certain fundamental problems with due process mechanism era as it were just like the way it was with the federal and other states that adopted the system.

First, there is absence of strong enabling legal framework to regulate public procurement practices. The Oyo state dueprocess mechanism was merely an ad hoc arrangement. The activities and operations of Oyo state due process mechanism do not have the force of law. Most of the decision and actions are haphazard and therefore could not be enforced. Secondly, the Oyo state Due Process stage could not substantially reduce or eradicate corruption. There exists opportunities for collusion among contractors and public officials to perpetrate corrupt practices. Public advertisements of government contract do not guarantee openness, and transparency. Thirdly, due diligence were not strong enough as engineers, accountants, architects and other certifying officials become honey pot for corrupt manipulation through collusions and compromise. With the promulgation of Public Procurement Law by the federal government in 2007 however, it was apparent that the standards for procurement practices have shifted. The public procurement law 2007 became a critical challenge to all the 36 states and all the 774 local government in Nigeria. Oyo state government was able to key into the new public procurement regime sometimes in December 2010 when the Oyo State Procurement Law 2010 was signed into law. 


\section{Basic Features of Oyo State Public Procurement Law 2010}

The objective principle of public procurement law, 2010 in Oyo state is to pro-actively respond to reform exigencies in public sector procurement system in order to ensure fairness, competition, transparency and cost accuracy [18]. It is also aimed at institutionalizing culture of effectiveness and efficiency in the implementation of budgetary expenditures. The Public Procurement Law, 2010 also seeks to eliminate waste, reduce corruption and recurring incidences of abandoned projects.

Essentially, the Oyo State Public Procurement Law, 2010 has some major resemblance with Public Procurement, 2007 of the Federal government of Nigeria. The areas of difference are in the extent of domestications as well as on issues of taking ownership of the process. While the Public Procurement Law 2007 applies only to federal procurements, the Oyo state Public Procurement Law 2010 focuses only on Oyo state. Whereas, with Public Procurement Law 2007 people are given wider opportunities to take full charge of the process, the Oyo state Public Procurement Law 2010 gives too much of ownership and power to the executives in public procurement process and management. Other major highlights of the Oyo State Public Procurement Law 2010 are as follows:

Part 1 of the Oyo state Public Procurement Law, 2010 establishes the Oyo state Public Procurement Council. It specifies membership of the council. Other key features of part 1 of the law is that it makes Permanent secretary, Oyo state Bureau of Public Procurement (BPP), the secretary of the council, while the Special Adviser to the Governor on Due Process; Commissioners for Finance, Justice, Head of Service are permanent members. Other members are representatives of Nigeria Bar Association (NBA), Nigerian Society of Engineers (NSE) Civil Society Organizations' (CSOs') and the Media are part-time members. It specifies the functions of Oyo State Public Procurement Council. Part 11 of Oyo State Public Procurement Law, 2010 establishes the Oyo State Bureau of Public Procurement (BPP), the roles, functions and powers of the bureau. It makes the Special Adviser to the Governor (Due Process) the head and chief executive officer of the bureau while it makes the Permanent secretary the accounting officer. It also defines the tenure of the office of the permanent secretary which is four-year term that is renewable only once. Part 111 defines the scope of application of Oyo State Public Procurement Law 2010. The law shall apply only to all procurement of goods, works and services carried out by the Oyo state government and all her procurement entities.

Part IV establishes fundamental principles for procurement in Oyo state. Some of these principles are the imperatives of setting thresholds, and needs for procurement plans; use of competitive bidding, specifying bidders' qualifications/requirement etc. Part V of Oyo State Public Procurement Law, 2010 focuses on organization of procurements. It gives definitions and legal status to approving authority, procurement planning, initiative on bids, competitive opening and it specifies, role of tender board and procurement entity. Part VI specifies the legal methods for procurements of goods and services. It exemplifies procedures invitation to bid, bids examination, bid validity period, rejection of bid, conditions for bid modification or withdrawals and bid evaluation. Part VII of Oyo State Public Procurement Law 2010 specifies conditions for domestic preference and also makes it legal for proper recording of procurement proceedings. Part VIII gives legal conditions for special and restricted methods of procurement including direct procurement while Part IX focuses on legal conditions for procurement of consultancy services and the procedures for request for proposals (RFP), clarification and modification of request for proposal, proposal evaluations and setting criteria for proposal selection. Part X of Oyo State Public Procurement Law, 2010 establishes legal framework for procurement surveillance and reviews, while Part XI deals with procedures for disposal of public properly. Finally, the final Part which is part XII of Oyo State Public Procurement Law 2010 defines codes for public procurement and specifies penalties for infractions or any forms of contravention.

\section{Anti-corruption measures incorporated into the procurement law}

The provisions of the Code of Conduct for Public Procurement in S.57 of the Act are focused on anticorruption. It is applicable to all public officers, suppliers, contractors and service providers. The binding principles of the Code are honesty, accountability, transparency, fairness and equity and public officers involved in public procurement and disposal of assets are required to subscribe to an oath as approved by the NCPP. It comprehensively defines conflict of interest situations and binds every public officer involved in public procurement or disposal of assets to divest himself of any relationship which is actually or potential detrimental to the best interest of government and the underlining principles of the PPA.

The Code of Conduct is applicable when making requisition for or planning of procurements; preparing solicitation documents; receiving offers in response to any form of solicitation towards a procurement or disposal; evaluating and comparing offers confidentially and in complete neutrality; protecting the interest of all parties without fear or favour; and obviating all situations likely to render an officer vulnerable to embarrassment or undue influence. Public officials are bound to declare conflict of interest situations so that a remedial action will follow such a declaration. There is also a Code of Conduct binding on procurement observers. Contractors, suppliers and service providers are under obligation at the pain of punishment not to compromise the system. Provision for access to procurement information is provided by S.38 of the PPA. It entitles contractors, service providers and the general public to procurement information after the conclusion of the proceedings whether it led to a contract award or not. S.38 (3) which seeks to oust the jurisdiction of the courts in matters of compelling disclosure is not only against international best practices but also unconstitutional considering S1 (3) of the 1999 Constitution.

Transparency is enhanced by the provision requiring procuring entities to maintain file and electronic copies of procurement proceedings for a period 10 years and to transit a copy to the BPP within three months after the end of the financial year to which the records relate. Procuring entities are to make available to the public all unclassified 
procurement records at the cost of copying and certifying plus an administrative charge as may be prescribed by the BPP from time to time. The provisions of the Freedom of Information Act 2011 which grants Nigerians access to all unqualified official records also weighs heavily on the side of access to procurement information. The PPA has provisions for the participation of civil society groups and professional associations in procurement proceedings.

\section{E. Effective enforcement and sanction mechanism}

The PPA contains provisions for a sanctions mechanism which seeks make its implementation effective. The categories of persons who may be liable for offences under the PPA include public officers, bidders, contractors, natural and artificial persons. The Attorney-General of the Federation is authorised to initiate prosecution under the PPA or he may authorize the Attorney General of a state or any legal practitioner. Public officers found guilty of contravening the law attract not less than five calendar years imprisonment without an option of fine and summary dismissal from government service. A legal person that violates the law attracts debarment from public procurement for a period of not less than five calendar years plus a fine equivalent to $25 \%$ of the value of the procurement in issue. The directors of the artificial person will also be guilty of an offence punishable by three calendar years but not exceeding five calendar years without an option of fine.

The designated offences include entering or attempting to enter into a collusive agreement for increasing the price of goods services or construction; conducting or attempting to conduct procurement fraud through undue influence, interest favour, bribery and corruption; contract splitting; unduly influencing procurement proceeding; bid rigging; uttering and using fake documentation; altering documentation with intent to influence proceedings, etc. The offences may be discovered through procurement surveillance and review by the relevant authority which is the Economic and Financial Crimes Commission and the Independent Corrupt Practices Commission or it could be discovered during administrative review of the proceedings.

At the administrative level, the Accounting Officer of the MDA involved in a breach of the law could be disciplined by the NCPP on the recommendation of the BPP; the suspension of officers concerned with the particular procurement and the replacement of the head or any of the members of a tenders Board as the case may be.

\section{RESEARCH METHODOLOGY}

This study was carried out through administration of structured closed and open-ended questionnaire(s) on the respondents that are involved in the public procurement process mechanism during contract procurement system. The questionnaires helped to present data on the understanding of public procurement and its compliance in the polytechnic tendering process, and survey of the official documents from Bursary Department was used to analyse the economic saving benefits of public procurement in the polytechnic.

The questionnaire was designed in a simple straight forward language with a Likert-like five (5) points scale measure. The summary of the findings on each question was based on score on each as a measure of high perception.
Questionnaire was administered on the sampled management staff and some key officials within the bursary, stores unit and works units of the polytechnic.

\section{RESULTS AND DISCUSSIONS RESPONSES FROM THE CONTRACTORS}

TABLE I: EXPERIENCE AND KNOWLEDGE OF PUBLIC PROCUREMENT LAW

\begin{tabular}{|c|c|c|c|}
\hline & & Frequency & Percent \\
\hline \multirow{5}{*}{$\begin{array}{l}\text { Years of experience did you } \\
\text { have as a contractor in the } \\
\text { polytechnic }\end{array}$} & $0-5$ years & 4 & 23.5 \\
\hline & $6-10$ years & 4 & 23.5 \\
\hline & $11-15$ years & 4 & 23.5 \\
\hline & $16-20$ years & 4 & 23.5 \\
\hline & \begin{tabular}{ll|}
$\begin{array}{l}\text { Above } \quad 20 \\
\text { years }\end{array}$ \\
\end{tabular} & 1 & 5.9 \\
\hline \multirow{5}{*}{$\begin{array}{l}\text { Numbers of projects executed } \\
\text { for the polytechnic }\end{array}$} & $0-5$ projects & 1 & 5.9 \\
\hline & 6-10 project & 6 & 35.3 \\
\hline & $\begin{array}{l}11-15 \\
\text { project }\end{array}$ & 6 & 35.3 \\
\hline & $\begin{array}{l}16-20 \\
\text { project }\end{array}$ & 2 & 11.8 \\
\hline & $\begin{array}{ll}\begin{array}{l}\text { Above } \\
\text { projects }\end{array} & 20 \\
\end{array}$ & 2 & 11.8 \\
\hline \multirow{4}{*}{$\begin{array}{l}\text { Level of understanding and } \\
\text { understanding and purposes of } \\
\text { public procurement law }\end{array}$} & Very well & 7 & 41.2 \\
\hline & Average & 7 & 41.2 \\
\hline & $\begin{array}{l}\text { Not } \\
\text { understood }\end{array}$ & 2 & 11.8 \\
\hline & Not sure & 1 & 5.9 \\
\hline
\end{tabular}

Table I shows that $23.5 \%$ of the respondents reported their years of experience from 0-5years, $23.5 \%$ reported 6-10 years of experience, $23.5 \%$ reported $11-15$ years while $5.9 \%$ reported above 20 years as a contractor in the polytechnic. $35.8 \%$ of the respondents reported that they have executed 610 years, $35.8 \%$ reported $11-15$ projects, $11.8 \%$ reported $16-$ 20 projects, $11.8 \%$ reported above 20 projects while $5.9 \%$ reported $0-5$ projects executed. Less than half (41.2\%) of the respondents reported that they have understanding the public procurement law very well, $41.2 \%$ reported average understanding of public procurement, $11.8 \%$ reported that they do not understand the purpose of public procurement while the least of the respondents were not sure of public procurement law. 
TABLE II: LEVEL OF IMPLEMENTATION OF PUBLIC PROCUREMENT LAW IN THE POLYTECHNIC

\begin{tabular}{|c|c|c|c|}
\hline & Response & Frequency & Percent \\
\hline \multirow{3}{*}{$\begin{array}{l}\text { Level of } \\
\text { implementation of } \\
\text { public procurement } \\
\text { law in the polytechnic }\end{array}$} & \begin{tabular}{|l} 
Very significant \\
\end{tabular} & 7 & 41.2 \\
\hline & \begin{tabular}{|l} 
Significant \\
\end{tabular} & 5 & 29.4 \\
\hline & Insignificant & 5 & 29.4 \\
\hline \multirow{3}{*}{$\begin{array}{l}\text { Duration of time it } \\
\text { take for public } \\
\text { procurement } \\
\text { certification process } \\
\text { to be completed in the } \\
\text { polytechnic }\end{array}$} & Less than 2 week & 4 & 23.5 \\
\hline & More than 2weeks & 9 & 52.9 \\
\hline & More than 4-weeks & 4 & 23.5 \\
\hline \multirow{3}{*}{$\begin{array}{l}\text { implementation of } \\
\text { public procurement } \\
\text { law in the polytechnic }\end{array}$} & Very effective & 5 & 29.4 \\
\hline & Effective & 9 & 52.9 \\
\hline & Not understood & 3 & 17.6 \\
\hline \multirow{4}{*}{$\begin{array}{l}\text { Duration of time it } \\
\text { take for public } \\
\text { procurement } \\
\text { certification to be } \\
\text { completed in the } \\
\text { polytechnic }\end{array}$} & Less than 2 week & 4 & 23.5 \\
\hline & More than 2 weeks & 9 & 52.9 \\
\hline & More than 4-weeks & 3 & 17.6 \\
\hline & More than 2 months & 1 & 5.9 \\
\hline \multirow{4}{*}{$\begin{array}{l}\text { Impact of the } \\
\text { implementation of } \\
\text { public procurement law } \\
\text { in the polytechnic }\end{array}$} & Very significant & 7 & 40.2 \\
\hline & Significant & 9 & 52.9 \\
\hline & Not sure & 1 & 5.9 \\
\hline & Total & 17 & 100.0 \\
\hline
\end{tabular}

Table II shows that $41.2 \%$ of the respondents reported that there are very significant implementation of public procurement law, 29.4\% reported that there are significant implementation of the public procurement law while $29.4 \%$ reported insignificant implementation of the public procurement law. More than half of the respondents reported that more than 2 weeks is the process of completing public procurement certificate, $23.5 \%$ reported that less than 2 week is the process of completing procurement certificate while $23.5 \%$ reported that more than 4 weeks is the process of completing public procurement certificate. More than half $(52.9 \%)$ of the respondents reported that the public procurement law is effective, $29.4 \%$ reported that the public procurement is very effective while $17.6 \%$ reported that the public procurement law is not understood. More than half of the respondents reported that more than 2 weeks is the process of completing public procurement certificate, $23.5 \%$ reported that less than 2 weeks is the process of completing procurement certificate, $23.5 \%$ reported that more than 2 weeks is the process of completing public procurement certificate while $5.9 \%$ reported that more than 4 weeks is the process of completing public procurement certificate. $40.2 \%$ of the respondent reported that the impact of the implementation of public procurement is significant and $52.9 \%$ reported very significant while $5.9 \%$ are not sure of its significance.
TABLE III: CHALLENGES AFFECTING THE IMPLEMENTATION OF PUBLIC PROCUREMENT LAW IN THE POLYTECHNIC

\begin{tabular}{|l|l|l|}
\hline & Frequency & Percent \\
\hline $\begin{array}{l}\text { Delay in public procurement certification and } \\
\text { release of contract document }\end{array}$ & 2 & 11.8 \\
\hline Delay in payment after contract completion & 5 & 29.4 \\
\hline $\begin{array}{l}\text { Delay in release of allocation from the state } \\
\text { account or from the polytechnic }\end{array}$ & 5 & 29.4 \\
\hline $\begin{array}{l}\text { Lack of implementation of appropriate } \\
\text { sanction against erring staff }\end{array}$ & 3 & 17.6 \\
\hline $\begin{array}{l}\text { Lack or awareness and understanding of the } \\
\text { public procurement law policies/procedures } \\
\text { among the stakeholder }\end{array}$ & 2 & 11.8 \\
\hline Total & 17 & 100.0 \\
\hline
\end{tabular}

Result in Table III shows that $29.4 \%$ of the respondents reported delay in payment after contract completion, $29.4 \%$ reported delay in release of allocation from the state, $17.6 \%$ reported lack of implementation public procurement as the challenges affecting the implementation, $11.8 \%$ reported lack of understanding public procurement while $11.8 \%$ reported that delay in public procurement certificate as the challenges affecting the implementation.

TABLE IV: RECOMMENDATIONS BY CONTRACTORS ON HOW TO IMPROVE THE IMPLEMENTATION OF PUBLIC PROCUREMENT LAW IN THE POLYTECHNIC

\begin{tabular}{|c|c|c|}
\hline & Frequency & Percent \\
\hline $\begin{array}{l}\text { Head of Departments, units and centres } \\
\text { should be trained on public procurement law }\end{array}$ & 5 & 29.4 \\
\hline $\begin{array}{l}\text { Needs orientation of the contractors on issue } \\
\text { relating to public procurement law }\end{array}$ & 6 & 35.3 \\
\hline $\begin{array}{l}\text { Inexperienced contractors are not allowed to } \\
\text { participate in the public procurement }\end{array}$ & 1 & 5.9 \\
\hline $\begin{array}{l}\text { Competent personnel should be allowed to } \\
\text { handle public procurement }\end{array}$ & 4 & 23.5 \\
\hline $\begin{array}{l}\text { The suppliers and printers should be carried } \\
\text { along }\end{array}$ & 1 & 5.9 \\
\hline Total & 17 & 100.0 \\
\hline
\end{tabular}

Table IV shows that $35.3 \%$ of the respondents reported that the management needs to orientate the contractor on issue public procurement law, $23.5 \%$ reported that the management needs competent personnel, $5.9 \%$ reported that the suppliers and printers should be carried along while $5.9 \%$ reported that the management does not need inexperienced contractor to participate in public procurement while $29.4 \%$ reported that head of departments, units and centres should be trained in public procurement law.

\section{RESPONSES BY THE STAFF}

TABLE V: EDUCATIONAL QUALIFICATION OF INSTITUTIONAL PROCUREMENT STAFF

\begin{tabular}{|l|l|l|}
\hline & Frequency & Percent \\
\hline M.Sc & 12 & 30.0 \\
\hline B.Sc, & 11 & 27.5 \\
\hline HND & 12 & 30.0 \\
\hline Secondary & 5 & 12.5 \\
\hline Total & 40 & 100.0 \\
\hline
\end{tabular}

Table $\mathrm{V}$ shows that $30.0 \%$ of the respondents obtained Higher National Diploma, 30.0\% obtained M.Sc, 27.5\% obtained B.Sc while $12.5 \%$ obtained Secondary School Certificate. 
TABLE VI: ASSESSMENT OF THE PROCESS MECHANISM OF PUBLIC PROCUREMENT LAW IN THE POLYTECHNIC

\begin{tabular}{|c|c|c|c|}
\hline & & Frequency & Percent \\
\hline \multirow{4}{*}{$\begin{array}{l}\text { Regulation and setting } \\
\text { standards to enforce } \\
\text { harmonized bidding and } \\
\text { tender document in this } \\
\text { institution }\end{array}$} & Very effective & 6 & 15.0 \\
\hline & Effective & 28 & 70.0 \\
\hline & Not understood & 4 & 10.0 \\
\hline & Very ineffective & 2 & 5.0 \\
\hline \multirow{4}{*}{$\begin{array}{l}\text { Formulation of general } \\
\text { policies and guidelines } \\
\text { on public procurement }\end{array}$} & Very effective & 2 & 5.0 \\
\hline & Effective & 30 & 75.0 \\
\hline & Not understood & 5 & 12.5 \\
\hline & Very ineffective & 3 & 7.5 \\
\hline \multirow{5}{*}{$\begin{array}{lrr}\text { Process of } & \text { upholding } \\
\text { Professional } & \text { ethnics } \\
\text { reporting } & \text { erring } \\
\text { personnel in } & \text { the } \\
\text { institution? } & & \\
\end{array}$} & Very effective & 6 & 15.0 \\
\hline & Effective & 18 & 45.0 \\
\hline & Not understood & 12 & 30.0 \\
\hline & Very ineffective & 4 & 10.0 \\
\hline & Total & 40 & 100.0 \\
\hline
\end{tabular}

Table VI shows that $70.0 \%$ of the respondents reported that they can effectively regulate the process to enhances harmonized document in the institution, $15.0 \%$ reported very effective to regulate and setting standard enforcement in the insitute, $10.0 \%$ reported that they didn't understand the settings while $5.0 \%$ were ineffective. $75.0 \%$ of the respondents reported that they effectively formulate the general policies and guideline on public procurement, $12.5 \%$ reported that they never understood the process of formulating general policies, $7.5 \%$ reported that they were very effective on formulating general policies and guideline on public procurement. Close to half $45.0 \%$ of the respondents reported that they effectively uphold professional ethnic of reporting erring personnel, 30.0\% reported that they did not understand, $15.0 \%$ reported that they were very effective in upholding professional ethnic of reporting erring personnel in the institution while $10.0 \%$ reported that they were ineffective.

TABLE VII: LEVEL OF IMPLEMENTATION PUBLIC PROCUREMENT LAW BY PUBLIC SERVANTS IN THE POLYTECHNIC

\begin{tabular}{|c|c|c|c|}
\hline & & Frequency & Percent \\
\hline \multirow{4}{*}{$\begin{array}{l}\text { The procedure of } \\
\text { documenting and } \\
\text { monitoring of public } \\
\text { procurement in the } \\
\text { institution? }\end{array}$} & Very effective & 6 & 15.0 \\
\hline & Effective & 29 & 72.5 \\
\hline & Not understood & 2 & 5.0 \\
\hline & Very ineffective & 3 & 7.5 \\
\hline \multirow{4}{*}{$\begin{array}{l}\text { The implementation of } \\
\text { public procurement } \\
\text { law in the polytechnic } \\
\text { generally? }\end{array}$} & Very effective & 1 & 2.5 \\
\hline & Effective & 22 & 55.0 \\
\hline & Not understood & 13 & 32.5 \\
\hline & Very ineffective & 4 & 10.0 \\
\hline \multirow{5}{*}{$\begin{array}{l}\text { Period it takes for } \\
\text { public Certification to } \\
\text { be completed in the } \\
\text { institution }\end{array}$} & .00 & 2 & 5.0 \\
\hline & Less than 2 week & 10 & 25.0 \\
\hline & More than 2weeks & 5 & 12.5 \\
\hline & More than 4-weeks & 7 & 17.5 \\
\hline & More than 2months & 16 & 40.0 \\
\hline
\end{tabular}

Table VII, shows that larger percentage of the respondents $29(72.5 \%)$ reported that the documentation and the monitoring of public procurement is effective, $15.0 \%$ reported very effective, $7.5 \%$ reported ineffective while $5.0 \%$ have poor understanding of the procedure. $55.0 \%$ of the respondents reported that they were effective implementing the public procurement law in the institute, $10.0 \%$ reported that they were ineffective about the implementation of public procurement law while $2.5 \%$ reported that they were very effective while implementing the procurement law in the institution and $32.5 \%$ have poor understanding of the procedure. Table 7 shows that $40.0 \%$ of the respondents reported that it took them more than 2 month to complete public certification, $25.0 \%$ reported less than 2 weeks to complete public certification, $17.5 \%$ reported more than 4 week to complete public certification in the institution while $12.5 \%$ reported that less than 2 weeks it took them to complete public certificate.

TABLE VIII: EXTENT OF CAPACITY BUILDING TRAININGS ON PUBLIC PROCUREMENT IN THE INSTITUTION

\begin{tabular}{|l|l|l|}
\hline & Frequency & Percent \\
\hline Never & 6 & 15.0 \\
\hline 2-times & 8 & 20.0 \\
\hline 3-times & 9 & 22.5 \\
\hline 4-times & 9 & 22.5 \\
\hline Above & 8 & 20.0 \\
\hline Total & 40 & 100.0 \\
\hline
\end{tabular}

Table VIII shows that $22.5 \%$ of the respondents reported that they attended capacity building training thrice, $22.5 \%$ also reported that more than three times visiting capacity building, $20.0 \%$ reported that that attended capacity building training twice while $20.0 \%$ reported that they visited capacity building training on public procurement in the institution more than 4times while $15.0 \%$ have never attended capacity building training on public procurement law.

H01: The Implementation of public procurement law has not made any significant impact on the execution of projects in the Polytechnic, Ibadan.

Table IX: Multiple regression analysis showing the impact of Implementation of public procurement law on the execution of projects in the Polytechnic, Ibadan

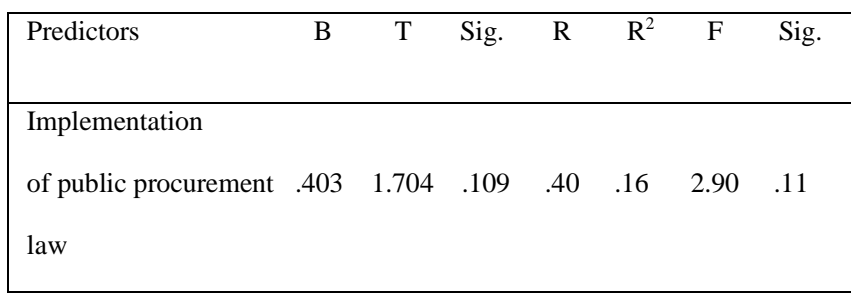

Dependent Variable: Perceived execution of projects in the Polytechnic, Ibadan

Results presented in Table IX reveal that Implementation of public procurement law was not a significant predictor of execution of projects in the Polytechnic, Ibadan $(\mathrm{R} 2=0.16$, $\mathrm{F}(1,15)=2.90, \mathrm{p}>.051)$. The result further revealed that Implementation of public procurement law contribution to execution of projects in the Polytechnic, Ibadan was not significant $(\beta=.40, t=1.70, \mathrm{p}>.05)$. The stated hypothesis was therefore accepted.

\section{CONCLUSION}

It is not a gain-saying that government all over the world is expected to provide services or public goods to the populace. However, this depends largely on the prudent and efficient utilization of those resources at her disposal. The 
importance of effective, transparency and accountability in government parastatals' spending cannot be over emphasized to guarantee the overall development of the country.

In the light of the above, this study use the Polytechnic, Ibadan as a case study and discovered that the contribution of the public procurement law to the execution of projects in the institution was not significant which is an indication that the compliance to the provisions of the procurement law is at lower ebb. [19] corroborated this finding that governmental institutions have become not only centralized and unaccountable, but they have become opaque, corrupt, selfserving and insensitive to the economic hardship of the country.

It is then important that the public procurement law of Oyo state must be reformed to accommodate the strict compliance to the provisions of the law by all parastatals in the state. If Nigeria nation must achieve the objectives of openness, transparency, probity, accountability and reduced corruption in line with global best governance institutional reform agenda, efforts should be intensified to deepen public procurement practices across all the government institutions.

\section{RECOMMENDATIONS}

From the findings of this study, the following recommendations are made;

1) Procurement officers in the institution should be hired on the basis of competency and professionalism and not on the basis of nepotism and favoritism as this will enhance and increase the level of accountability.

2) Transparency should be encouraged in the various stages of the public procurement process starting from invitation to bid, bid security, submission of bids, rejection of bids, to bid opening and awarding of contracts.

3) Contract should be carried out in such a way that will guarantee efficiency, value for money. Projects should be completed as scheduled and within stipulated cost.

4) There is need for intensive training for core procurement staff of all government parastatals. This will enable them to be able to actively participate in public procurement processes.

5) Public procurement monitoring and evaluation unit should be established in all government institutions to serve as watchdog on public procurement law compliance.

6) Strict sanction should be prescribed for anyone who has committed an infraction on public procurement law to serve as deterrent for subversion of public procurement law and process. The sanction should be applicable across board to all stakeholders, be it public servants or stakeholders from the private sector.

\section{REFERENCES}

[1] H. A., Huka, A. D. Mchopa and J. J. Kimambo, "Analysis of Procurement Procedures in Local Government Authorities: Experience after Procurement Reforms and Case Analysis from Selected Councils in Kilimanjaro Tanzania," European Journal of Business and Management, 6(18), 16-22. 2014.

[2] K. S. Benson \& J. O. Adeoye, "Investigating the Extent of Compliance with State Public Procurement Law: Lagos State as an Example.'
Journal of Public Administration and Governance, 10 (1), pp.239-248, 2020.

[3] E. Onyekpere, Public Procurement Reports, Abuja Centre for Social Justice, 2009.

[4] N. Seember, Manual on public procurement law 2007, Abuja public and private development center, 2012, www.ppdc.com

[5] E. W. Adeyeye, Oyo State Due Process and Governance Audit Report. Ibadan, Cope Africa, 2011.

[6] Ameyaw \& S. Mensah, "Curbing corruption in the public procurement process in Ghana," Public policy and administration research, 3 (5), 44-53, 2013.

[7] S. A. Ekanem. \& E. N. Ekefre, "Governance and corruption in Nigeria: A Philo-psychological management analysis Mediterranean" Journal of Social Science. Vol 4. No 14 Nov. 2013. Pp. 141-151, 2013

[8] Krivish and I. Krekele, "Challenges of Public Procurement in Projects with Multifunding in Project Management Development - Practice and Perspectives," 2nd International Scientific Conference on Project Management in the Baltic Countries, Riga, University of Latvia, 2013

[9] S. J. Evenett and B. Hoekman, "International cooperation and the reform of public procurement policies," Policy Research Working Paper 3720, Washington, DC: World Bank, 2005.

[10] O. E. Unaam \& J. Mark, "Effect of ethics and integrity on good public procurement system," International journal of arts and humanities, 4(1), 168-176, 2005.

[11] United Nations Commission on International Trade Law (UNCITRAL), "Model Law on Public Procurement," New York UN Publication, 2014.

[12] Adewoye, "Governance reform and the challenge of implementing public procurement law regime across Nigerian state and local governments," International Journal of Public Administration and Management Research, 2(4), 25-32, 2014.

[13] Asare and A. J. Bentum, Public Procurement Management. 2nd ed., New York: McGraw Hill, 2009.

[14] Basheku, "Public procurement reforms in Africa: A tool for effective governance of the public sector and poverty reduction," International handbook of public procurement, Boca Raton, CRC Press, 2009.

[15] NIGP, "Transparency in government procurement," Herndon, VA: NIGP, 2008.

[16] Adeyeye, "Governance reform and public procurement law regime in Nigerian federating states: a case study of Oyo State," International Journal of development and economic sustainability, 3(1): 18-29, 2015.

[17] BMPIU, "A manual on public procurement reform programme in Nigeria," State House, Abuja, Nigeria, 2015

[18] COPE, "Public Procurement Regime in Nigeria," Cope Africa monograph series 2, 2011.

[19] Okwoli, "Value for Money Auditing in Nigeria: Its Problem and Prospects in the Next Millenium," Public Policy and Administrative Research 2(6), pp.6-9, 2011.

Adebisi, Kolawole Shittu teaches Sociology, Psychology and Law related subjects in the General Studies Department of the Polytechnic Ibadan, Nigeria. He obtained National Diploma in Financial Studies from the same Polytechnic, holds Bachelor of Science and Master of Science Degrees in Sociology with area of specialization in Industrial Sociology and Law Degrees LL.B and LL.M. all from the Premier University of Ibadan, Nigeria and Barrister in Law from the Nigerian Law School. His research interests are Human Resources Management, Sociology of Development, Corporate Law Administration and Criminology.

$\mathrm{He}$ is an International Associate Member of American Sociological Association (ASA), a Member of Nigerian Anthropological and Sociological Practitioners Association (NASA), an Associate Member, American Psychological Association (APA), an Associate Member of Nigeria Institute of Management (NIM), a Full Member of Nigeria Institute of Local Government and Public Administration, a Member of Association of Nigerian Academics (ANA) and Nigerian Bar Association (NBA). Adebisi has attended several conferences, workshops and seminars at both National and International levels and has several publications in various National and International Academic Journals 